\title{
Improving the Ability in Writing Narrative Text of Junior High School Students through Peer Feedback
}

\author{
Mochammad Noor \\ SMP Negeri 13 Samarinda, Indonesia \\ Pascasarjana Universitas Negeri Malang, Indonesia \\ e-mail: mochammadnoor28@yahoo.co.id
}

\begin{abstract}
:
This study employed classroom action research to investigate the impact of peer feedback strategy towards the improvement of eighth graders' ability in writing narrative text. Planning, implementing, observing, and reflecting were conducted in one cycle that consisted of 7 meetings in which, 6 meeting for implementing the stages of peer feedback strategy, and 1 meeting for conducting the writing test. The result showed that students' average score improved 13.86 points from the preliminary study result and got $91.2 \%$ positive responds from the students after this strategy had been implemented. From the findings can be seen that student's narrative writing is found improved through peer feedback. Students' responses toward peer feedback activity in EFL writing classroom were mostly positive. It can be concluded that peer feedback was an interesting alternative besides teacher feedback. Under certain condition, peer feedback was said more intensive than other approach and this gives them chances to be aware on their mistakes in writing. Overall, students' revised version drafts are more developed and this is in line with previous research result that peer feedback is beneficial and advantageous. As suggested by researchers and teachers, peer feedback should be implemented thoroughly, carefully, and well-planned and this has been examined in this research; a not well-planned peer feedback might lead to a failure.
\end{abstract}

Keywords: writing ability, peer feedback strategy 


\section{Introduction}

The students, at SMP Negeri 13 Samarinda, were indicated that their ability in the language skills especially in writing was still insufficient. Most of students were failed to pass from the minimum criterion of passing grade (KKM) of English subject. This regard was caused by that there were some problems in teaching and learning writing in class which needed to be overcome. In teaching and learning process the teacher provides fewer portions in writing activities for the students in class. In addition, the strategies used in teaching and learning process were not varied and uninteresting because the students had to do the writing activities in under pressure. As a result, the students were not enthusiastic in writing activities and thus become bored easily. When the teacher was asking them to write, most of them seemed very nervous and neglected the assignment, even they could produce nothing for a period of time because they did not know what to do and how to do it. It showed that they face difficulties to do the assignment. The teacher also dominated the teaching and learning process that made a passive learning.

Another fact was that some students had negative attitude about writing or lack confidence to write something. Even, they were bored waiting for their teachers' feedback on their papers, until finally they never got their papers back. Looking at this condition, the teachers were faced with changing their attitudes and building confidence. In other to make the students more confident to write, designing a good writing activity such as peer feedback was necessary to build. Peer feedback was the simplest way that could be used by the teacher. It became the simple way since it let the students wrote and corrected their friends' paper then provided opportunities for them to do experiment with a story as narrative text. In this case the writing activities by using peer feedback should be arranged in sequence from simple to more complexes, from concrete experience to imaginative visualization.

Regarding those reasons, there must be a special strategy that could be used to solve the problems. In this research, the researcher proposed a special strategy called peer feedback, which could be matched with both genre-based approach and process writing approach based on the context of teaching writing for Junior High School in Indonesia. As a matter of fact, teaching writing for EFL students in Indonesia has become harder since they move up to higher grade. For Junior High School students, they usually have to face more complicated writing, like writing a narrative, a recount, and many other of paragraph. In writing those assignments, EFL students should have known about what they were going to write and what they were going to correct.

Peer feedback is strongly recommended by some researchers who support this approach (e.g., Kamimura, 2006; Zeng, 2006; Jiao, 2007; Hirose, 2009; Fauzan, 2016; Chew, 2016; and Rollinson, 2005); because peer feedback allows students negotiate their ideas, commenting and correcting mistakes in their peer's drafts, offering suggestions for their peer's draft development (Spear, 1998; Williams, 2005), although according to Clark (2003) the development achieved by the students is seemed superficial. Nevertheless, peer feedback is shown as an alternative 
applicable to improve students' writing (skill and text) under certain condition (Hyland \& Hyland, 2006).

The researcher indicates that peer feedback has certain impact on students' writing, and based on the background above, this research was performed to investigate the impact of peer feedback on the students 'narrative writing and students' responses toward peer feedback activity in EFL writing classroom. Rollinson (2005) mentions that the students respond peers feedback activities as beneficial. In line with this, Jacobs et al (1998) stated that they believe that students usually welcome peer feedback as one type of feedback in writing classroom.

\section{Research Methodology}

The description of research method that will be employed in this study, including research design, setting and subjects of the study, and research procedures in the cycle that consists of planning, implementing, observing, and reflecting.

\subsection{Research Design}

The design of this study was a classroom action research. It meant that when doing the study, the researcher as an English teacher of the eight graders of SMPN 13 at Samarinda, was a person who inspired the classroom in applying the peer feedback strategy as the actual action in the teaching and learning process. In the other words, in implementing the action, the researcher acted as a teacher and researcher (Mulyasa, 2009).

Koshy (2006) claimed that an important feature of action research is that it offers opportunities for collaborative work. Team work is very essential. This means that a teacher-researcher cannot work by himself so, he has to be assisted by a collaborator. It has been a common practice in classroom action research to have a collaboration partnership to observe the teaching learning process.

The design of this classroom action research was in the form of cycles referring to the model of Kemmis and McTaggard (Latief, 2013:146), which consists of four steps: planning the action, implementing the action, observing, and reflecting. If the first cycle failed, the design should be continued to Cycle 2. When this cycle also fails, it has to be continued to Cycle 3 and so forth.

\subsection{Research Setting and Subjects}

This site of the research is the eighth graders of SMP Negeri 13 at Samarinda which consist of 30 students. Those considerations are taken into account in hoping that peer feedback, as the classroom action research, can be implemented in writing narrative in English, although peer feedback is originally formulated to be used in English as L1 (Hyland \& Hyland, 2006), teachers and researchers (e.g., Spear, 1988; Hyland, 2005; Williams, 2005; Zeng, 2006; Kamimura, 2007) are optimist that peer feedback might be valuable in Junior High School students if the students are well trained (Williams, 2005; Lim, 2007) and have sufficient knowledge of what and how to do it (Clark, 2003). In line with those assumptions, the above criteria are taken into consideration to perform the participant recruitment. 


\section{Findings}

The findings obtained when the researcher was conducted at SMP Negeri 13 Samarinda. It presents the improvement of the students' ability in writing, implementation of peer feedback strategy, and the responses of the students.

\subsection{The Improvement of the Students' Ability in Writing}

The result of preliminary study showed that most students still wrote ungrammatically, lack of vocabulary, and use inaccurate capitalization and punctuation. After implementing the stages of peer feedback strategy, the students' writing tended to be better from time to time. Comparing between the stories were written in preliminary study and written along the process of implementing the peer feedback strategy showed that the students succeeded improving their writing ability.

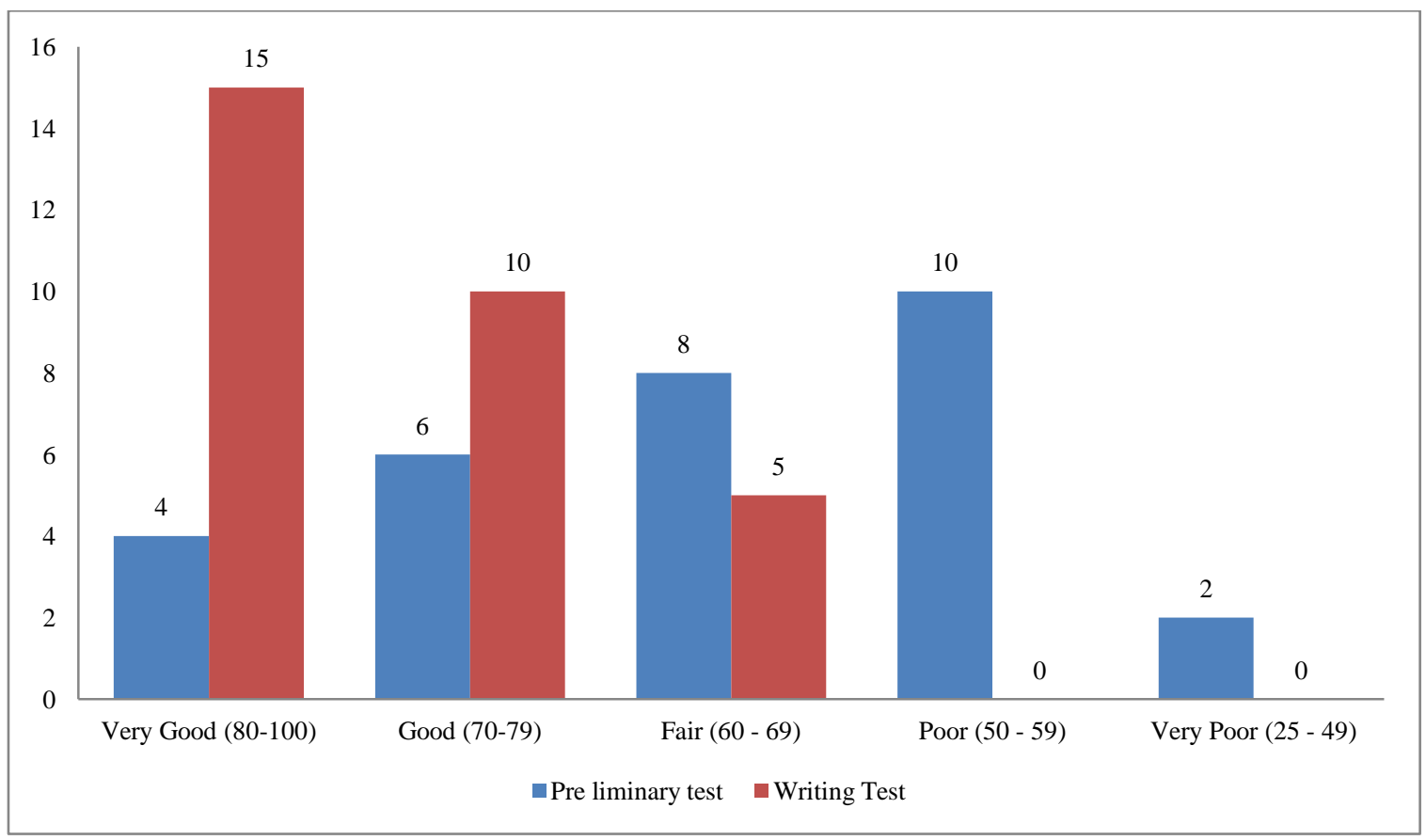

Figure 1. Students' Achievement Level in Preliminary Test and in the Writing Test

The data shows that the result of the students' achievement level in writing narrative text improved from preliminary test. There were fifteen students or 50\% from the total number of the students in this class who were in very good level, ten $(33.33 \%)$ students achieved 70-79 as in good level, and $16.66 \%$ or five students got in fair level. Meanwhile, there was none in the lowest level. The minimum passing standard $(K K M)$ of this school is 70 , so there were 25 students or $83.33 \%$ of the students who passed in this test. 
From the preliminary test result could be found that there were 12 students who were in the poor and very poor level, meaning that they were the lowest students in this test. So, these students became the main focus to be improved about their score.

Table 1. The Lowest Students' Point Improvement

\begin{tabular}{llllll}
\hline No & Students' Name & Sex & Pre- Test & $\begin{array}{l}\text { Post- } \\
\text { Test }\end{array}$ & $\begin{array}{l}\text { Point } \\
\text { Improvement }\end{array}$ \\
\hline $\mathbf{1}$ & S6 & F & 55 & 65 & $\mathbf{1 0}$ \\
$\mathbf{2}$ & S11 & M & 55 & 65 & $\mathbf{1 0}$ \\
$\mathbf{3}$ & S21 & F & 55 & 80 & $\mathbf{2 5}$ \\
$\mathbf{4}$ & S24 & F & 55 & 75 & $\mathbf{2 0}$ \\
$\mathbf{5}$ & S25 & M & 55 & 80 & $\mathbf{2 5}$ \\
$\mathbf{6}$ & S28 & F & 55 & 80 & $\mathbf{2 5}$ \\
$\mathbf{7}$ & S8 & M & 50 & 75 & $\mathbf{2 5}$ \\
$\mathbf{8}$ & S12 & M & 50 & 70 & $\mathbf{2 0}$ \\
$\mathbf{9}$ & S16 & F & 50 & 65 & $\mathbf{1 5}$ \\
$\mathbf{1 0}$ & S19 & M & 50 & 80 & $\mathbf{3 0}$ \\
$\mathbf{1 1}$ & S23 & F & 45 & 65 & $\mathbf{2 0}$ \\
$\mathbf{1 2}$ & S4 & M & 40 & 65 & $\mathbf{2 5}$ \\
\hline
\end{tabular}

From the Table above can be seen that there were 12 students who were in the position of the lowest level, the data were taken from the result of preliminary score. After doing the post test in the seventh meeting, the researcher found that the score of those students improved 10 until 30 points from the result of preliminary test.

\subsection{Implementation of peer feedback Strategy}

There were two stages in peer feedback strategy that be implemented by the researcher to the students, those are pre-action (explaining, training, modelling), and post-action (practicing). These stages were divided into 6 meeting in which the explaining stage was done on the first meeting; the training stage had been passed on the second meeting, meanwhile the modelling stage was delivered on third meeting, and the last stage, the practicing was implemented on the fourth, the fifth, and sixth meeting. In the first meeting, the researcher started to introduce the strategy that the students should implement in the process of learning to write narrative text was the peer feedback strategy. In the next meeting, the students were training about how to be a good reviewer. The next activity was modelling. In this session, the researcher taught the students about how to give feedback to a draft. In this activity, the researcher used the peer feedback guidance to review the text

The last stage of the implementing peer feedback strategy was the practicing. This stage was held on the fourth, fifth, and sixth meeting. This session constituted the time for the students to develop their writing ability by receiving the feedback from the peer in the class. The students started writing a story based on the outline of the story that made before. After that, they sit in their group, exchanging the draft to one another, and then revised the draft based on the peer's feedback, and the last was submitted the revised draft to the researcher. 


\subsection{The Responses of the Students}

In order to know about the students' responses, the researcher distributed the questionnaire to the students at the end of the meeting 7 . The questionnaire consists of ten questions. The first item in the questionnaire was about the students' interest in writing. It was reported that $(60 \%)$ of the students or (18) students strongly liked the writing lesson, and (40\%) or 12 students liked writing lesson. From the data, it was inferred that generally the students' interest in writing lesson were good.

The second item in the questionnaire was the students' opinion about their motivation learning in group. (43\%) of the students or 13 students agreed that writing skill was very easy, and $(43 \%)$ of the students or 13 students agreed that writing skill was important. It was concluded that most students thought that writing was easy. The third item in the questionnaire was about the students' opinion about their motivation writing a text in group. 14 students or $47 \%$ of the students claimed that their writing ability is good, 11 students claimed that their writing ability was not good, and 5 students claimed that their ability in writing was very bad. From this data, it was concluded that mostly the students in the class believed that they had good writing ability.

For item number 4, it was to know whether the students liked working in group or not. The result was 13 students liked working in group so much, 14 students liked working in group, and the rest 3 students disliked work in group. From the previous data, it was inferred that the students liked and enjoyed working in group in writing lesson. From item 5, the item was related to the students' feeling when their friends read and corrected their writing essay. Surprisingly, 17 students or $57 \%$ of the students answered that they were very pleasant when their friends read and gave feedback to their writing essay, 13 students or $43 \%$ students answered that they were okay. It was concluded that overall students liked if their friends involved in their writing process by welcoming their peers to read their draft and getting feedback from them.

Item number 6 was the students' opinion about the feedback given by their friends. 20 students or $67 \%$ of the students found that their peers' feedback was very helpful and could enrich their essay. 8 students or $27 \%$ of the students felt that their peers' feedback was helpful, and the rest 2 students' or $7 \%$ of the students answered that peers' feedback was not helpful and could not lead to the betterment of their essay writing. This data showed that students had positive attitude toward the implementation of peer feedback, moreover, their friends' feedback had lead them to write better. The following item was about the students' opinion about their writing after given feedback by their peers. 24 students or $80 \%$ of the students answered that after receiving feedback from their peers, their writing was much better than before, 4 students or $13 \%$ students answered that their writing was better, and $7 \%$ of the students or 2 students answered that their writing was not better at all after receiving feedback from their peers.

Item number 8 was about the students' feeling when they were asked to read their peers' draft. 6 students or $20 \%$ of the students responded that they was very happy 
when they read their friends' draft, 20 students or $67 \%$ of the students was happy when they read their friends' draft, and the rest 4 students disliked when they were asked to read their friends' draft. So, it was concluded that most students liked when they were asked to read their friends' writing essay. Number 9 in the questionnaire asked the students' opinion whether reading their peers' draft gave them more idea to write or not. The result showed that 14 students or $47 \%$ of the students was very agreed that reading other's draft gave more ideas, 11 students or $37 \%$ of the students agreed, and 5 students or $17 \%$ disagreed that reading other's draft gave them more ideas.

The last item was number 10 . The question was related to the students' opinion about peer feedback strategy. 19 students or $63 \%$ of the students were strongly agreed that peer feedback strategy used in writing lesson could motivate them to write, 10 students or $33 \%$ of the students agreed that peer feedback strategy used in the writing could motivate the students to write, and the rest 1 students or $3 \%$ of the students answered disagree that peer feedback strategy could motivate the students to write. For all above data obtained from questionnaire, it could be concluded that there were $91.2 \%$ answers from the students had positive responses towards the implementation of peer feedback strategy to improve the students' ability in writing narrative text.

\section{Discussion}

This section focuses on the discussion of the implementation of peer feedback strategy. The discussions include the students' writing ability, the implementation of peer feedback strategy, and the students' responses towards the implementation of peer feedback.

\subsection{The Improvement on students' writing ability}

The result of the implementation of peer feedback in this study showed that there was improvement on the students' writing. This was evidenced by students' score of post writing test which showed improvement from the score of preliminary study. Another fact is from the students' draft after being revised. The students revised their draft based on their peers' feedback, comment, and suggestions. After being revised, their draft was better than their first draft. Besides, the students could have chance to discuss with their friends about their draft, which part of their draft that was still wrong and needed improvement and also shared opinion about each other. This was really different when they only rely on the teacher's feedback. Often the teacher only pays attention on the grammar aspect by circling, underlining the mistake sentences without giving explanation why so. Rollinson (2005) stated that peer feedback is less threatening than teacher's feedback. It is also less authoritarian and more supportive.

The result of this study appeared to confirm the result of some previous study about the implementation of peer feedback in the classroom conducted by Tsui and $\mathrm{Ng}$ (2000). A study conducted by Tsui and Ng (2000) with secondary school students in Hong Kong has identified four distinct benefits of peer review. First, writing for peers enhances learners' sense of audience, encouraging them to pay more attention 
to issue of clarity in their written work. Second, peer review makes students more aware of general problems in their own writing. Third, peer review encourages students' sense ownership of their own writing, helping to promote learner autonomy. Fourth, it is easier for students to decide whether to accept or reject the reviewer's suggestions. Another study is by Mubarok (2009) which finds out that the implementation of peer feedback can improve the writing ability in the third year students.

\subsection{The Implementation of Peer Feedback Strategy}

Peer feedback is not only about how the students make interaction and negotiation of ideas, furthermore, peer feedback starts from the preparation of the class. The first stage in implementing peer feedback strategy is that the students must be introduced with related concepts (in this research the concepts were peer feedback and narrative writing). The teacher should carefully teach the students about peer feedback activity (what, why, and how to do it) (Spear, 1988; and Wijaya, 2000). The next stage was distributing device that would be used in the peer feedback activity. The device might be in form of checklist, rubric, or other from that can be used by the students to give feedback correctly (Spear, 1988; Hyland, 2005; and William, 2005).

The next stage after distributing peer feedback devices was training the students to do peer feedback. Students needed to understand peer feedback activity completely by doing that. Training students can give them sense of the peer feedback purposes and the potential benefits of that activity (William, 2005). Training students before implementing peer feedback was crucial for the activity to be truly profitable (Rollinson, 2005). Another researcher who emphasizes the essentiality of training is Lim (2007). Lim stated that EFL students could benefit similarly (with L1 students) if teachers implemented the peer feedback procedure carefully and give students substantial training.

The next stage was the students started writing their draft (Narrative in this research), sharing their draft, reading and giving feedbacks, revising their draft, and submitting their draft. One important thing suggested by Spear (1988) is that the teacher should make the students aware that they are not "object" but they are "subject" in the process. The students were demanded to be active and reactive in interacting in this process. Another important thing must be paid attention in this process is suggested by Rollinson (2005). Rollinson suggests that students must be made aware that they are collaborators rather than correctors. This shows that the students do not only correct mistakes found in their peer's writing, but also offering meaningful and useful inputs for their peer's writing further development.

\subsection{Students' responses towards the implementation of peer feedback}

The result of the observation towards students' responses during the teaching and learning process showed positive result. Although, it was still found that there were some students who did not actively engaged in the discussion due to their personal problems. Theoretically, peer feedback gives positive impact for the students since writing and learning are social process. In this study, by implementing feedback 
activities, the students could interact with their classmates and also could work together.

In this study, the students seemed enjoyed writing activities. It was proven by result of questionnaire. Most students felt enjoy when they worked with their group. They felt their friends' comment is less threatening than their teacher. They could ask their friends when they did not understand without being underestimated. It is also witnessed by Hyland's (2003) statement which said that basically, students are able to participate actively in learning activities while getting response from the readers in a non-threatening situation.

\section{Conlusion and Suggestion}

\subsection{Conlusion}

From the findings can be seen that student's narrative writing is found improved through peer feedback. Students' responses toward peer feedback activity in EFL writing classroom were mostly positive. It can be concluded that peer feedback was an interesting alternative besides teacher feedback. Under certain condition, peer feedback was said more intensive than other approach and this gives them chances to be aware on their mistakes in writing. Overall, students' revised version drafts are more developed and this is in line with previous research result that peer feedback is beneficial and advantageous. As suggested by researchers and teachers, peer feedback should be implemented thoroughly, carefully, and well-planned and this has been examined in this research; a not well-planned peer feedback might lead to a failure.

\subsection{Suggestions}

For an English teacher who has the same problem, he or she can use this strategy as one of alternative strategy in teaching. However, before implementing this strategy, it will be better for the teacher to pay attention to some aspects. In the very beginning, the teacher should explain what the function of peer feedback strategy is and why they should know and apply it. This makes them aware on how important peer feedback is for their better writing. The researcher also should give model on how to give meaningful feedback also should provide clear peer review guidance for the students. It is also important to arrange the member of the group based on English performance. Each group should have a leader who is smarter than the other so that $\mathrm{s} / \mathrm{he}$ can control and lead group discussion during feedback sessions. For the future researchers who want to conduct similar study, it will be better to implement this strategy by combining with the digital media that can impress students to write a text and also conducting this strategy with the other genre texts.

\section{References}

Agustiningsih, D. (2005). Implementing Peer Assessment to Improve the Writing Ability to the Second Year Students of SMP Negeri 4 Palu. Thesis. Unpublished. Malang: Graduate Program in English Language Education State University of Malang. 
Al-Qurashi, F.M. (2009). Saudi Students' Reactions to Peer Response Groups in EFL Composition Classroom. Journal of King Saud University - Language and Translation Vol. 21, P.57-67.

Bartels, N. (2003). Written Peer Response in L2 Writing. English Teaching Forum. Vol. 41(1), P. 34-36.

CHEW, Phyllis Ghim-Lian. (2016). Language Use and Discoursal Strategies in Peer Religious Mentoring. Journal of English Language Teaching and Linguistics, $1(3), 2016$

Clark, I.L. (2003). Concepts in Composition: Theory and Practice in the Teaching of Writing. London: Lawrence Erlbaum Associates Publishers.

Emilia, E. (2010). Teaching Writing: Developing Critical Learners. Bandung: Rizqi Press.

Fauzan, Umar. (2016). Enhancing Speaking Ability of EFL Students through Debate and Peer Assessment. EFL JOURNAL, I(1), 2016. http://dx.doi.org/10.21462/eflj.v1i1.8

Harmer, J. (2007). How to Teach Writing. Essex: Pearson Longman

Heaton, J. B. (1990). Writing English Language Test. Hongkong: Longman

Hirose. K. (2009). Cooperative Learning in English Writing Instruction through Peer Feedback. Unpublished Research. Nagakute City: Aichi Prefectural University.

Hong, F. (2006). Students Perception of Peer Response Activity in English Writing Instruction. CELEA (Bimonthly) Aug. 2006. Vol. 29 No.4 P.48-68

Hyland, K. (2005). Second Language Writing. Cambridge: Cambridge University Press.

Hyland, K. \& Hyland, F. (2006). Feedback in Second Language Writing: Context and Issue. Cambridge: Cambridge University Press.

Jacobs, G.M., Curtis, A., Braine, G., \& Huang, S-Y. (1998). Feedback on Students Writing: Taking the middle Path. Journal of Second Language Writing, Vol. 7, P. 307-317.

Jiao, L. Y. (2007). Application of Cooperative Learning in Teaching College English Writing. US-China Foreign Language. ISSN 1539-8080, USA. Vol. 5 No. 5 (Serial N0. 44) P.104-137

Kamimura, T. (2006). Effects of Peer Feedback on EFL Student Writers at Different Levels of English Proficiency: A Japanese Context. TESL Canada Journal. Vol.23, No.2, Spring 2006, P.12-39.

Kirszner, L. G \& Mandell, S. R. (2008). Focus on Writing Paragraphs and Essays. Boston: Bedford/St Marin's.

Latief, M. A. (2013). Research Methods on Language Learning an Introduction. Malang: State University of Malang Press.

Nunan, D. (1998). The Learner-Centered Curriculum. Cambridge: Cambridge University Press.

Rollinson, P. (2005). Using Peer Feedback in the ESL Writing Class. ELT Journal: Jan 2005; 59, 1; ProQuest Education Journals P.23-30.

Spear, K. I. (1988). Sharing Writing: Peer Response Groups in English Classes. Portsmouth: Boyton/Cook Publisher. 
Tompkins, G.E. (2008). Teaching Writing: Balancing Process and Product. Fifth Edition. New Jersey: Pearson Merril Prentice Hall.

Wardani, H.S. (2011). The Use of Peer Feedback to Improve the Writing Ability of the Eight Graders of MTsN Bangkalan. Thesis. Unpublished. Malang: Graduate Program in English Language Education State University of Malang.

Wegle, S. C. (2002). Assessing Writing. Cambridge: Cambridge university Press.

Williams, J. (2005). Teaching Writing in Second and Foreign Language Classroom. Boston: McGraw Hill.

Zeng, Y. (2006). Peer Feedback in College SLW Classroom. Sino-US English Teaching, ISSN 1539-8072, USA. Mar. 2006, Vol.3, No. 3 (serial No. 27) P.64-81. 